\title{
OPTIMALISASI JUMLAH ANAKAN PRODUKTIF PADI DENGAN PENGAIRAN MACAK-MACAK SERTA PENAMBAHAN PUPUK P DAN K
}

\author{
${ }^{1}$ Rudi Wardana, ${ }^{2}$ Irma Hariyati \\ ${ }^{1}$ Program Studi Teknologi Produksi Tanaman Pangan Jurusan Produksi Pertanian, ${ }^{2}$ Program Studi \\ Managemen Bisnis Unggas Jurusan Peternakan Politeknik Negeri Jember \\ Jl. Mastrip Jember Kotak Pos 164 Jember \\ rudiwardana19@gmail.com
}

\begin{abstract}
Abstrak
Peningkatan hasil produksi padi masih perlu dioptimalkan dengan cara intensifikasi seperti penggunaan bibit unggul, pemupukan serta perbaikan teknologi pascapanen. Pengairan juga merupakan suatu komponen yang penting untuk meningkatkan hasil produksi padi. Pemupukan yang dilakukan harus mempertimbangkan kebutuhan tanaman terhadap unsur hara, pada fase vegetatif sampai fase generatif. Tujuan dari penelitian ini adalah untuk mengetahui pengaruh penggunaan sistem pengairan macak-macak dengan penambahan unsur hara $\mathrm{P}$ dan $\mathrm{K}$ terhadap optimalisasi peningkatan jumlah anakan produktif padi. Metode yang digunakan yaitu menggunakan pengairan macak-macak dengan penambahan pupuk $\mathrm{P}$ dan $\mathrm{K}$ dengan dosis $50 \mathrm{~kg} / \mathrm{ha}, 100$ $\mathrm{kg} / \mathrm{ha}, 150 \mathrm{~kg} / \mathrm{ha}$, dan $200 \mathrm{~kg} / \mathrm{ha}$. Hasil penelitian ini menunjukan bahwa perlakuan tersebut menghasilkan data yang tidak berbeda nyata untuk semua paramater pengaman, dengan signifikansi 0,634 pada tinggi tanaman 4 MST, 0,848 untuk signifikansi jumlah anakan produktif dan 0,403 untuk signifikansi bobot 100 bulir padi. Jumlah anakan produktif terbanyak terdapat pada perlakuan MP4 yaitu 15 anakan.
\end{abstract}

Kata kunci : Padi, Pengairan macak-macak, Pupuk P dan K

\begin{abstract}
Increased rice production still needs to be optimized by means of intensification such as the use of quality seeds, fertilizer and improvement of post-harvest technology. Watering is also an important component to increase the yield of rice production. Fertilization is done should consider the nutrient needs of plants, the vegetative phase to the generative phase. The purpose of this study was to determine the effect of the use of irrigation systems macak-macak with the addition of nutrients $\mathrm{P}$ and $\mathrm{K}$ on the optimization of the increase in the number of productive tillers of rice. The method used is using irrigation macak-macak with the addition of $\mathrm{P}$ and $\mathrm{K}$ fertilizer with a dose of $50 \mathrm{~kg} / \mathrm{ha}, 100 \mathrm{~kg} / \mathrm{ha}, 150 \mathrm{~kg} / \mathrm{ha}$ and $200 \mathrm{~kg} / \mathrm{ha}$. These results indicate that treatment of the produced data were not significantly different for all safety parameters, with 0.634 significance in plant height 4 MST, 0,848 for the significance of the number of productive tillers and 0.403 for significance weight of 100 grains. The number of productive tillers MP4 highest one is on the treatment of 15 puppies.
\end{abstract}

Keywords

: $P$ and K fertilizers, Productive tillers, Rice (Oryza sativa L.), Watering macak-macak

\section{PENDAHULUAN}

Kebutuhan padi di Indonesia selalu mengalami kenaikan pada setiap tahunnya, dengan kenaikan sebesar 0,44\% per tahun (BPS, 2014). Hal ini dikarenakan pertumbuhan penduduk Indonesia yang juga mengalami peningkatan sebesar 1,4\% per tahun (BPS, 2015). Kecenderungan masyarakat Indonesia untuk menjadikan padi sebagai bahan makanan pokok merupakan penyebab naiknya kebutuhan padi selain pertambahan penduduk.

Peningkatan hasil produksi padi masih perlu dioptimalkan dengan cara intensifikasi dan ekstensifikasi. Langkah intensifikasi seperti penggunaan bibit unggul, pemupukan serta perbaikan teknologi pascapanen terbukti dapat meningkatkan produksi padi (Setyono, 2010). Pengairan juga merupakan suatu komponen yang penting untuk meningkatkan hasil produksi padi. Menurut Taufik dkk., Taufik, dkk (2006) menyatakan bahwa tanaman padi yang diairi dengan kondisi kapasitas lapang dan pengariran sistem basah kering "macak-macak" memberikan hasil produksi padi tertinggi.

Hasil produksi padi berkaitan dengan jumlah anakan yang dihasilkan, semakin banyak jumlah 
Rudi Wardana, Irma Hariyati, Optimalisasi Jumlah Anakan Produktif Padi Dengan Pengairan Macak-Macak Serta Penambahan Pupuk P dan K

anakan yang dihasilkan maka semakin tinggi hasil anakan padi tersebut mampu untuk menghasilkan malai, atau disebut juga dengan anakan produktif. Anakan produktif dihasilkan dengan pemberian unsur hara yang seimbang. Pemupukan berimbang merupakan aplikasi pupuk ke dalam tanah dengan tujuan untuk mencapai kondisi status hara tanah yang esensial dan optimum, sehingga dapat meningkatkan kesuburan tanah, mutu dan hasil produksi, efisiensi pemupukan dan mengurangi pencemaran lingkungan (Setyorini, dkk. 2006).

Pemupukan yang dilakukan harus mempertimbangkan kebutuhan tanaman terhadap unsur hara. Unsur $\mathrm{N}$ dibutuhkan oleh tanaman pada saat pertumbuhan atau fase vegetatif, sebab $\mathrm{N}$ pada tanaman memiliki fungsi sebagai pembentuk klorofil dan protein, sedangkan unsur hara $\mathrm{P}$ dan $\mathrm{K}$ dibutuhkan pada saat fase generatif, sebab unsur hara $\mathrm{P}$ berfungsi sebagai penyimpan dan transfer energi, komponen penting asam nukleat, nukleotida, koenzim, fosfolipid, dan gula fosfat. Unsur hara $\mathrm{K}$ pada tanaman berfungsi sebagai pembentukan karbohidrat, aktifasi enzim dan katalisator penyimpanan fotosintat (Hartatik, 1990). Berdasarkan latar belakang di atas, maka penelitian mengenai optimalisasi jumlah anakan produktif dengan pengairan macak-macak dan penambahan pupuk $\mathrm{P}$ dan $\mathrm{K}$ perlu dilakukan.

Penelitiaan ini bertujuan untuk mengetahui pengaruh penggunaan sistem pengairan macakmacak dengan penambahan unsur hara $\mathrm{P}$ dan $\mathrm{K}$ terhadap optimalisasi peningkatan jumlah anakan produktif padi.

\section{METODOLOGI}

Penelitian ini dilaksanakan di lahan Penelitian Politeknik Negeri Jember, Kecamatan Sumbersari, Kabupaten Jember pada bulan Agustus sampai November 2016.

Alat yang digunakan dalam penelitian ini yaitu: ayakan, alat ukur (meteran kain atau penggaris), timbangan analitik, kamera, alat tulis, spidol, gembor, timba, dan gayung, sedangkan bahan yang digunakan dalam penelitian ini adalah: benih padi varietas ciherang, pupuk kompos, pupuk Urea, SP-36, KCl, kertas label dan pestisida.

Penelitian ini dilakuakan dengan menggunakan Rancangan Acak Kelompok (RAK) dengan non faktorial. Aplikasi pupuk $\mathrm{P}$ dan $\mathrm{K}$ susulan dilakukan pada 2 MST dan 4 MST dengan dosis terdiri dari 4 level yaitu

- $\mathrm{P} 1=$ pupuk $\mathrm{P}$ dan $\mathrm{K}$ dosis masing-masing 50 $\mathrm{kg} / \mathrm{Ha}$

- $\mathrm{P} 2=$ pupuk $\mathrm{P}$ dan $\mathrm{K}$ dosis masing-masing 100 $\mathrm{kg} / \mathrm{Ha}$

- $\mathrm{P} 3=$ pupuk $\mathrm{P}$ dan $\mathrm{K}$ dosis masing-masing 150 $\mathrm{kg} / \mathrm{Ha}$ produksinya. Hal ini bisa terjadi jika kondisi dari - $\mathrm{P} 4=$ pupuk $\mathrm{P}$ dan $\mathrm{K}$ dosis masing-masing 200 $\mathrm{kg} / \mathrm{Ha}$

sedangkan untuk teknis pengairannya yaitu tanah diairi hingga berapa pada kondisi di atas kapasitas lapang (keadaan air macak-macak). Kondisi ini dibiarkan selama fase pertumbuhan tanaman, dan sampai 10 hari menjelang panen kondisi tanah sudah mulai dikeringkan.

Berdasarkan perlakuan tersebut, maka penelitian ini terdiri dari 4 kombinasi, dengan masing perlakuan diulang $6 \mathrm{kali}$, sehingga total unit menjadi 24 unit. Tata letak blok pada penelitian dapat dilihat pada Tabel 1 .

Tabel 1. Tata letak blok penelitian

\begin{tabular}{|l|l|l|l|l|l|}
\hline Blok1 & Blok2 & Blok 3 & Blok 4 & Blok5 & Blok 6 \\
\hline MP1 & MP3 & MP1 & MP3 & MP2 & MP4 \\
MP2 & MP4 & MP3 & MP2 & MP1 & MP2 \\
MP3 & MP1 & MP2 & MP1 & MP3 & MP3 \\
MP4 & MP2 & MP4 & MP4 & MP4 & MP1 \\
\hline Ket & M pengairan dengan kondisi macak-macak \\
P & = penambahan pupuk susulan P dan K
\end{tabular}

Pupuk yang digunakan adalah pupuk anorganik seperti : Urea, SP-36 dan KCl. Pupuk urea diberikan 3 kali aplikasi yaitu $40 \%$ dosis Urea diberikan sebagai pupuk dasar bersama seluruh pupuk SP-36. $50 \%$ dosis pupuk $\mathrm{KCl}$ diberikan pada saat tanaman umur $7 \mathrm{hst}, 30 \%$ dosis Urea diberikan pada saat anakan produktif umur $21 \mathrm{hst}$ dan $30 \%$ dosis Urea bersama $50 \%$ dosis $\mathrm{KCl}$ diberikan pada saat tanaman umur 40 hst. Aplikasi pupuk kompos dilakukan bersamaan dengan persiapan media tanam, sedangkan untuk pupuk tambahan $\mathrm{P}$ dan $\mathrm{K}$ dilakukan pada 2 MST dan 4 MST.

Pengamatan dilakuakan meliputi kompenen pertumbuhan vegetatif dan kompenen hasil. Pengamatan pada pertumbuhan vegetatif padi sawah meliputi:

- Tinggi Tanaman: Pengukuran tinggi tanaman dengan cara mengukur padi dari permukaan tanah (pangkal batang) hingga ujung daun tertinggi pada minggu ke 4 setelah tanam

- Jumlah anakan produktif (Jumlah malai perumpun): Anakan produktif dihitung dari jumlah anakan atau batang yang mengaluarkan malai per rumpun pada saat sebelum panen (13 MST)

- Bobot bulir per 100 butir: Bulir padi bernas yang berasal dari gabah yang diambil secara komposit kemudian ditimbang dari setiap unit sejumlah 100 butir yang diulang 2 kali

Data yang diperoleh dianalisis dengan sidik ragam (ANOVA), dan apabila hasil analisis antar perlakuan terjadi perbedaan yang signifikan maka 
dilanjutkan dengan uji lanjutan Duncan's Multiple

\section{HASIL DAN PEMBAHASAN}

Kebutuhan tanaman akan air sangat diperlukan untuk pertumbuhan sebab air mengisi sekitar 70-90\% pada tubuh tanaman dan juga berkaitan dengan aktifitas metobolisme pada tanaman. Menurut Juliardi dan Ruskandar (2006) mengatakan bahwa air yang diperlukan untuk pengolahan tanah sampai siap tanam (selama 30 hari) dapat menghabiskan air sebanyak $20 \%$ dari total kebutuhan air untuk padi sawah, sedangkan pada fase bunting sampai pengisian bulir (selama 15 hari) menghabiskan air sebanyak $35 \%$. Pengairan macak-macak merupakan suatu kondisi tanah lembab akan tetapi tidak tergenang, sehingga
Range Test (DMRT) dengan taraf 5\% kondisi seperti ini dapat menyediakan oksigen pada tanah.

Pemupukan pada tanaman diarahkan pada kondisi yang seimbang serta memperhatikan kebutuhan dari tanaman berdasarkan fase pertumbuhan. Unsur hara $\mathrm{N}$ dibutuhkan pada fase pertubuhan. Unsur hara $\mathrm{P}$ dan $\mathrm{K}$ untuk penyimpanan dan pembentukan karbohidrat (Hartatik, 1990).

Berdasarakan hasil penelitian tentang optimasi pembentukan anakan produktif dengan pengairan macak-macak dan penambahan pupuk $\mathrm{P}$ dan $\mathrm{K}$, maka diperoleh data seperti pada Tabel 2 berikut ini:

Tabel 2. Rerata hasil pengamatan tinggi tanaman, anakan produktif, dan berat 100 bulir

\begin{tabular}{|c|c|c|c|c|l|}
\hline \multirow{2}{*}{ Perlakuan } & \multicolumn{4}{|c|}{ Dosis pupuk P dan K per Hektare } & \multirow{2}{*}{ Rerata } \\
\cline { 2 - 5 } & $50 \mathrm{~kg}$ & $100 \mathrm{~kg}$ & $150 \mathrm{~kg}$ & $200 \mathrm{~kg}$ & \\
\hline \multirow{2}{*}{$\begin{array}{c}\text { Macak- } \\
\text { macak }\end{array}$} & 79,06 & 78,63 & 80,83 & 79,83 & Tinggi tanaman $(\mathrm{cm})$ \\
\cline { 2 - 6 } & 11,5 & 11,83 & 11,33 & 12,17 & Jumlah anakan produktif (buah) \\
\cline { 2 - 5 } & 2,57 & 2,58 & 2,62 & 2,56 & Berat 100 bulir (gr) \\
\hline
\end{tabular}

\section{Tinggi Tanaman}

Fase pertumbuhan pada tanaman dapat dihitung dengan beberapa parameter, salah satu parameter yang digunakan adalah dengan melakukan pengamatan terhadap tinggi tanaman. Pengamatan tinggi tanaman padi dilakukan pada usia padi 4 MST. Pengamatan dilakukan pada minggu ke empat didasarkan pada fase pertumbuhan tanaman padi optimal pada usia tersebut (Yosida, 1981 dalam Subagyo dkk, 2004). Tabel 1 di atas memperlihatkan bahwa rerata untuk tinggi tanaman hampir sama pada setiap perlakuan yaitu antara $78-81 \mathrm{~cm}$.

Berdasarakan hasil analisis sidik ragam menunjukkan bahwa perlakukan tidak berpengaruh nyata dengan nilai signifikansi sebesar 0,634 , hal ini berarti bahwa pengairan macak-macak dengan penambahan pupuk $\mathrm{P}$ dan $\mathrm{K}$ pada masing-masing perlakuan tidak memberikan perbedaan tinggi tanaman yang nyata atau dapat dikatakan bahwa rata-rata tinggi tanaman padi usia 4 MST sama untuk setiap perlakukan. Hasil ini didasarkan pada kebutuhan pupuk untuk fase pertumbuhan lebih mengarah pada pupuk $\mathrm{N}$ yang berperan pada pertumbuhan (Hartatik, 2006).

\section{Jumlah Anakan Produktif}

Anakan padi tumbuh diantara dasar batang dan daun sekunder. Anakan pertama padi akan muncul setelah berusia 10 HST dan maksimum akan berakhir setelah barusia 50-60 HST, akan tetapi ini bergantung pada jenis varietasnya (Aak, 1990). Anakan produktif akan muncul pada saat menjelang masuk pada fase generatif atau pembentukan malai, sehingga anakan produktif diidektikkan dengan jumlah anakan yang menghasilkan malai. Berdasarkan tabel 1 menunjukkan bahwa rereta jumlah anakan produktif yang paling tinggi berada pada perlakuan MP4 dengan jumlah anakan produktif sebanyak 12 tanaman.

Berdasarakan hasil analisis sidik ragam menunjukkan bahwa perlakuan berbeda tidak nyata dengan nilai signifikansi 0,848 . hal ini berarti bahwa pengairan macak-macak dengan penambahan pupuk $\mathrm{P}$ dan $\mathrm{K}$ pada masing-masing perlakuan tidak memberikan perbedaan jumlah anakan yang nyata atau dapat dikatakan bahwa rata-rata jumlah anakan sama untuk setiap perlakukan. Hal ini kemungkinan disebabkan oleh kondisi curah hujan yang tinggi yang menyebabkan pemupukan yang dilakukan akan ikut oleh aliran air sehingga mengakibatkan tanaman tidak mampu memaksimalkan penyerapan unsur hara. Menurut Dobermann and Fairhust 2000, dalam Andriawan 2010 menyatakan bahwa unsur hara yang berperan penting untuk pembentukan jumlah anakan adalah $\mathrm{N}$ dan $\mathrm{P}$.

\section{Bobot Bulir per 100 Butir}

Perhitungan potensi hasil produksi padi bisa dilakukan dengan cara menimbang bobot bulit dari padi. Bobot bulir padi diketahui dengan cara 
Rudi Wardana, Irma Hariyati. Optimalisasi Jumlah Anakan Produktif Padi dengan Pengairan Macak Macak Serta Penambahan Pupuk P dan K.

mengambil 100 butir bulir padi yang bernas kemudian ditimbang dengan menggunakan timbangan analitik. Rata-rata hasil perhitungan bobot 100 bulir padi yaitu antara 2,3 gram sampai 2,7 gram hal ini sesuai dengan karakter dari Balai Besar Penelitian Padi (2009), yang menyebutkan bahwa bobot 1000 butir padi ciherang adalah 28 gram.

Berdasarkan hasil analisis sidik ragam menunjukkan bahwa perlakuan pengairan macakmacak dengan penambahan pupuk $\mathrm{P}$ dan $\mathrm{K}$ tidak berbeda nyata dengan nilai signifikansi sebesar 0,403. Perbedaan pada berat bulir terjadi akibat perbedaaan ukuran dan juga bentuk dari bulir padi, pada varietas yang sama akan menghasilkan bentuk dan ukuran bulir padi yang relatif sama, sebab perbedaan karakter pada bulir padi ditentukan oleh faktor genetik yang dimiliki oleh padi ciherang (Rahimi, dkk. 2012).

\section{KESIMPULAN}

Berdasarkan hasil dan pembahasan di atas maka dapat disimpulkan bahwa:

a. Perlakukan tidak berpengaruh nyata terhadap tinggi tanaman umur 4 MST dengan nilai signifikansi sebesar 0,634.

b. Jumlah anakan produktif yang dihasilkan tidak berbeda nyata dengan nilai signifikansi 0,848 . Jumlah anakan produktif yang paling tinggi berada pada perlakuan MP4 yaitu sebanyak 15 anakan produktif.

c. Rata-rata hasil perhitungan bobot 100 bulir padi yaitu antara 2,3 gram sampai 2,7 gram dengan signifikansi sebesar 0,403 yang berarti perlakukan tersebut tidak berbeda nyata.

Adapun saran dari penelitian ini adalah perlu dilakukan uji lanjutan mengenai ketepatan dalam penambahan pupuk $\mathrm{P}$ dan $\mathrm{K}$, serta teknik aplikasinya, sehingga dapat menghasilkan tanaman dengan produksi yang optimal.

\section{UCAPAN TERIMA KASIH}

Penulis mengucapkan terima kasih kepada Kapala Pusat Penelitian dan Pengabdian kepada Masyarakat (P3M) Politeknik Negeri Jember yang telah memberikan dana DIPA dengan Nomor : SP DIPA-042.01.2.401005/2016 Tanggal 7 Desember 2015.

\section{DAFTAR PUSTAKA}

AAK. 1990. Budidaya Tanaman Padi. Yogyakarta: Kanisius.

Andriawan,I. 2010. Efektivitas Pupuk Hayati Terhadap Pertumbuhan dan Hasil Padi Sawah
(Oryza sativa L.) [Skripsi]. Departemen Agronomi dan Hortikultura. Institut Pertanian Bogor

Badan Pusat Statistik. 2014. Data Produksi Padi Tahun 2011-2015. http://www.bps.go.id/b. [diakses 13 Agustus 2016]

Badan Pusat Statistik. 2015. Data Laju Pertumbuhan Penduduk Menurut Provinsi Tahun 2010-2014. http://www.bps.go.id/brs. [diakses 13 Agustus 2016]

Balai Besar Penelitian Tanaman Padi. 2009. Deskripsi Varietas Padi. Sukamandi: Departemen Pertanian.

Hartatik, W., Widowati, L.R. 1990. Pengaruh Pupuk Majemuk NPKS dan NPK terhadap Pertumbuhan dan Hasil Padi Sawah pada Inceptisol. Penelitian Pertanian Tanaman Pangan. Vol. 34 No. 3. 2015.

Juliardi, I, dan A. 2006. Ruskandar. Teknik Mengairi Padi Kalau macak-macak cukup, mengapa harus digenang?. Tabloid Sinar Tani.

Rahimi, Z., E. Zuhry, dan Nurbaiti. 2012. Pengaruh Jarak Tanam terhadap Pertumbuhan dan Produksi Padi Sawah (Oryza sativa L.) Varietas Batang Piaman dengan Metode SRI di Padang Marpoyan Pekanbaru. http://repository.unri.ac.id [diakses 01 Nopember 2016]

Setyono, A. 2010. Perbaikan teknologi pascapanen dalam upaya menekan kehilangan hasil padi. Pengembangan Inovasi Pertanian. 3(3):212226.

Setyorini dkk. 2006. Kompos dalam Pupuk Organik dan Pupuk Hayati (Organic Fertilizer and Biofertilizer). Balai Besar Litbang Sumberdaya Lahan Pertanian. Balai Penelitian dan Pengembangan Pertanian. Balittanah. litbang.pertanian.go.id. [diakses 13 Agustus 2016]

Subagyono. K, dkk. 2004. Pengelolaan Air pada Tanah Sawah dalam Lahan Sawah dan Teknologi Pengelolaannya. Pusat Penelitian dan Pengembangan Tanah dan Agroklimat. Departemen Pertanian. http://balittanah.litbang. pertanian.go.id [diakses 10 Agustus 2015].

Taufik, M., Arafah, Nappu, B., Djufry, F. 2014. Analisis Pengelolaan Air dalam Usaha Tani Padi Pada Lahan Sawah Irigasi di Sulawesi Selatan. BPTP Sulawesi Selatan. 
